\title{
Nutritional Status of 1-5 Years Children of the Tea Workers in Sylhet Division
}

\author{
SYED SHAFI AHMED MUAZ ${ }^{1}$, MD. RABIUL HASAN², SHAMIM AHMED SHAMIM ${ }^{3}$ \\ ARCHANA DEV ${ }^{4}$, SAIMA KAMAR ${ }^{5}$
}

\begin{abstract}
A cross-sectional community based study was conducted in four tea gardens of Sylhet division to assess the nutritional status of 1 to 5 years children of tea workers. Nutritional status was determined anthropometrically along with their socioeconomic background and the nutritional status was compared with the data obtained from national survey. Prevalence of wasting was $42.3 \%$ whereas that of stunting and underweight was $80.2 \%$ and $73 \%$ respectively. All these parameters are significantly higher than those obtained from national data (BDHS, 07). Though the children are breast fed at much higher rate in comparison with Bengali children, their mother's educational status and body mass index are lower than that of Bengali population. The nutritional status of children of tea workers are worse than that of national level.
\end{abstract}

Key words: Tea workers, nutritional status.

\section{Introduction}

Nutrition is a dynamic process involving food values, food processing, digestion and assimilation of food for nourishing the body. Malnutrition results from inadequate food intake, increased nutrients needs, decreased nutrient absorption and/ or increased nutrient losses ${ }^{1}$. Nutritional assessment by anthropometric measurement, is an important technique for identifying individuals, groups or communities whose growth is not keeping up with the expected pattern. A child born today in developing world has four out of ten chances living in extreme poverty $^{2}$. A survey of World Bank showed that $49.8 \%$ of our people lived below poverty line in the year 2000 according to cost of basic needs (CBN) method. Among them $53 \%$ was of rural origin and $36.6 \%$ lived in urban area $^{3}$. Another survey showed that $40.9 \%$ of the people in our country was below poverty line in 2004 according to daily calorie intake (DCI) method ${ }^{4}$.

1. Associate Professor and Head, Department of Paediatrics, Jalalabad Ragib-Rabeya Medical College and Hospital (JRRMCH), Sylhet

2. Registrar, Department of Paediatrics, JRRMCH, Sylhet

3. Assistant Professor, Department of Paediatrics, JRRMCH, Sylhet

4. Assistant Registrar, Department of Paediatrics, JRRMCH, Sylhet

5. Lecturer, Department of Microbiology, JRRMCH, Sylhet Correspondence: Dr. Syed Shafi Ahmed Muaz
As a result of poverty and other socioeconomic factors, malnutrition in young children is endemic in many developing countries including Bangladesh. Data obtained from different rounds of Child Nutrition Survey conducted by Bangladesh Bureau of Statistics (BBS) showed that the child nutrition status is improving day by day. About $32.9 \%$ of the total population of Bangladesh are below 14 years of age and only $43.1 \%$ people are literate (age 15 year and over who can read and write) $)^{5}$. Over population, poverty and illiteracy are pervasive in Bangladesh, causing population hazards like malnutrition. Malnutrition hampers body's metabolism along with retardation of immune system ${ }^{6}$. Bairagi and Chowdhury showed that mother's education, family income, sex and birth order of the children are important determinant of malnutrition ${ }^{7}$. Islam and Rahman in their study, found a significant relationship between mother's education and nutritional status of children ${ }^{8}$. There is a part and parcel relationship among poverty, health education and ethnic origin or social status. The ethnic minority populations are numerous and diverse in Bangladesh. There are 45 different tribal groups in Bangladesh with a total population of more than 12 lakh $^{9}$. The tea workers of Bangladesh are a cornered, subaltern group of people with a multitribal ethnic origin. The number of tea garden is 158 by 2000, covering an area of 48,300 hectares. Of these gardens, 135 are in 
Sylhet division and 23 are Chittagong division. Bangladesh produces about 55 million $\mathrm{kg}$ of tea each year occupying the $9^{\text {th }}$ position in respect of production in the world. About 0.15 million people are directly employed in tea industry along with $3,50,000$ dependants which constitutes about 3.3 percent of the country's total employment ${ }^{10}$. Sixty percent workers of this industry are female and tea sector contributes about $0.81 \%$ of GDP in Bangladesh ${ }^{10}$. The tea workers are generally known as 'Coolie'. They are not the indigenous people of the country. Most of them are the descendants of the workforces recruited by the colonial planters from Orissa, Bihar, Madras, and Central Province of India in the middle of $18^{\text {th }}$ century. They are from different tribal groups including Saotal, Munda, Orao, Lohar, etc. Almost all the tea workers are Hindu and literacy rate among them is very low as they are employed into garden works in their childhood which is more profitable to them ${ }^{11}$. The food habit of tea workers is very simple. They eat rice, bread, vegetables, tea, dried fish (shutki), etc. A special food is made of smashed green leaves of tea. Meat is usually taken during religious or marriage ceremonies. Drinking wine (rice bear) is a common practice and it is supplied with the assistance of the administration of the tea gardens ${ }^{12}$. So, as observed, their ethnic origin, culture, feeding practice, literacy rate and profession are different from those of indigenous Bengali people. As these are very important determinants for nutrition, it is expected that there will be an obvious difference in the nutritional status of 1 to 5 years children of tea workers from that of Bengali children.

\section{Materials and Methods}

This is a community based cross sectional study. It was conducted in 4 tea gardens which were randomly selected by lottery method from 135 tea gardens in Sylhet division representing 4 geographical locations to avoid any biasness of the data.

The sample size was determined by using the following formula: $\mathrm{N}=(\mathrm{pq}) \mathrm{z}^{2} / \mathrm{d}^{2}$. Where, $\mathrm{N}=$ sample size; $\mathrm{p}=\mathrm{As}$ prevalence rate was not known, 0.5 proportions was taken as prevalence at $5 \%$ significant level; $z=1.96$; $\mathrm{d}=$ marginal error or precision; $\mathrm{q}=1-\mathrm{p} ; 5 \%$ acceptable marginal error $=0.05$.

So, minimum sample size was 384 children but for more accuracy, data was collected from 800 children and samples were divided into four groups from one to five years. It was expected that at least $10 \%$ of these data might have to be excluded from analyses because of dropouts or unusual health condition. Sample was selected by stratified sampling. The quantitative data was collected by anthropometric measurements and qualitative data was gathered through case studies. Children with congenital anomalies, chronic debilitating diseases or with nurodevelopmental disabilities were excluded from the study. They were examined for variables like height / supine length, weight and mid upper arm circumference (MUAC). Information regarding their mothers' nutritional status, feeding practices, family income, healthcare practices and educational status were also investigated.

A questionnaire was prepared for the purpose of the study. After taking written and verbal consent from mother/guardians all required data and samples were collected and then questionnaires were checked and crosschecked in order to correct inconsistency in information and coding. The data were analyzed by using SPSS PC version 10 to observe means, distributions and test of significance. Anthropometric data were analyzed by WHO standard for the classification of malnutrition. For reporting of height for age, weight for age and weight for height relative to the WHO reference percentile and Z score were used.

\section{Results}

This study was conducted upon 800 children. Among them 40 children were excluded from the study due to inadequate data. In the remaining 760 children, 405 were male (53.3\%) and 355 were female (46.7\%). There were 181 children in 1-2 year age group, 219 children in 2-3 year group and 187 in 3-4 year group and the last group (4-5 year) included 173 children. Male-female ratio of total children was 1.14:1. This study also included 210 attending mothers. Most of them belong to age group " $<18$ years" which was $64.8 \%$ of the attending mothers.

Lack of maternal education was an agonizing finding. One hundred and eighty nine mothers were found illiterate which comprises $90 \%$ of study population and no body passed HSC examination.

Table-I

Distribution of the maternal education $(n=210)$

\begin{tabular}{lcc}
\hline Education & Frequency & Percent \\
\hline Illiterate & 189 & 90.0 \\
$<$ SSC & 21 & 10.0 \\
$>$ SSC & 0 & .0 \\
\hline
\end{tabular}


Among 210 mothers, 10\% (21) experienced infant death and $8.6 \%$ (18) had history of abortion or stillbirth and $70 \%$ of them had monthly income of less than Tk. 2000.

\section{Table-II}

Distribution of monthly income of the family $(n=210)$

\begin{tabular}{lcc}
\hline Monthly income (in taka) & Frequency & Percent \\
\hline$<2000$ & 147 & 70.0 \\
$2000-3000$ & 44 & 21.0 \\
$3000-4000$ & 11 & 5.2 \\
$>4000$ & 8 & 3.8 \\
\hline
\end{tabular}

The tea workers are a breast feeding society. Prelacteal feeding like sugar water, honey was offered to only about $17 \%$ of the newborn and exclusive breast feeding was given about $80 \%$ of the children up to 6 months of age. Complementary feeding was started with rice gruel in $85 \%$ of cases and with khichuri in $10 \%$ of cases. The children of tea gardens have good coverage of EPI vaccination. Ninety five percent of the children are completely immunized according to EPI schedule. They also had a high rate of drinking tube well water (98.6\%) but only $51 \%$ of them used sanitary latrine and almost all of them live in kacha house (99.5\%) made of mud and bamboo. Body mass index of the attending mothers reveal that about half of the mothers (49.6\%) had BMI less than 18.5 and 9.6\% were severely malnourished with a BMI less than 16 (Table-III).
Table-III

Distribution of body mass index of mothers

\begin{tabular}{lcc}
\hline BMI $\left(\mathrm{Kg} / \mathrm{M}^{2}\right)$ & No. of mother & Percent \\
\hline$>20$ & 53 & 25.2 \\
$18.5-20$ & 53 & 25.2 \\
$16-18.4$ & 84 & 40.0 \\
$<16$ & 20 & 9.6 \\
\hline
\end{tabular}

Mid upper arm circumference of the children give an idea of severity of malnutrition among the study children. Fifty two percent of the children had MUAC less than $13.5 \mathrm{~cm}$ (Table-IV). The average percentage of wasting, stunting and under weight in the 1-5 years children was $42.3 \%, 80.2 \%$ and $73 \%$ respectively (Table-V).

Comparison of nutritional status of 1-5 years children obtained from Bangladesh demographic and health survey '07(BDHS) and the children of tea workers of this study revealed that in all parameters, i.e., weight for height, height for age and weight for age were significantly $(P<0.05)$ lower than those of national level (Table VI, VII, VIII).

Table-IV

Distribution of mid upper arm circumference (MUAC)

\begin{tabular}{lcc}
\hline MUAC & No. of children & Percent \\
\hline Green $(>13.5 \mathrm{~cm})$ & 365 & 48.0 \\
Yellow $(12.5-13.5 \mathrm{~cm})$ & 304 & 40.0 \\
Red $(<12.5 \mathrm{~cm})$ & 91 & 12.0 \\
\hline
\end{tabular}

Table-V

Distribution of nutritional status of the children in various age groups expressed in percentage

\begin{tabular}{|c|c|c|c|c|c|c|}
\hline \multirow{3}{*}{$\begin{array}{l}\text { Age } \\
\text { (year) }\end{array}$} & \multirow{2}{*}{\multicolumn{2}{|c|}{$\begin{array}{c}\text { Weight for height } \\
\text { Z score }\end{array}$}} & \multirow{2}{*}{\multicolumn{2}{|c|}{$\begin{array}{l}\text { Height for age } \\
\text { Z score }\end{array}$}} & \multirow{2}{*}{\multicolumn{2}{|c|}{$\begin{array}{c}\text { Weight for age } \\
\text { Z score }\end{array}$}} \\
\hline & & & & & & \\
\hline & $<-3$ & -2 to -3 & $<-3$ & -2 to -3 & $<-3$ & -2 to -3 \\
\hline $1-2$ & 8.8 & 38.1 & 21.5 & 49.7 & 15.5 & 59.7 \\
\hline $2-3$ & 6.9 & 36.5 & 24.2 & 59.8 & 16.9 & 52.5 \\
\hline $3-4$ & 7.5 & 32.1 & 25.1 & 64.2 & 15.0 & 58.3 \\
\hline $4-5$ & 4.6 & 34.7 & 19.1 & 57.2 & 14.4 & 59.5 \\
\hline
\end{tabular}


Table-VI

Distribution of nutrition status (wasting) of the children: Comparison between national data and result of the study

\begin{tabular}{|c|c|c|c|c|}
\hline \multirow{2}{*}{$\begin{array}{l}\text { Age } \\
\text { (year) }\end{array}$} & \multirow[b]{2}{*}{ Study group } & \multicolumn{2}{|c|}{$\begin{array}{l}\text { Weight for height (wasting) } \\
\text { Z score }\end{array}$} & \multirow{2}{*}{ p value* } \\
\hline & & Moderate (-2 to -3$)$ & Severe $(<-3)$ & \\
\hline $1-2$ & $\begin{array}{l}\text { BDHS, } 07 \\
\text { Tea workers' children }\end{array}$ & $\begin{array}{c}250(23.2)^{\#} \\
69(38.1)\end{array}$ & $\begin{array}{l}43(4.0) \\
16(8.8)\end{array}$ & 0.001 \\
\hline $2-3$ & $\begin{array}{l}\text { BDHS, } 07 \\
\text { Tea workers' children }\end{array}$ & $\begin{array}{l}174(16.1) \\
80(36.5)\end{array}$ & $\begin{array}{l}21(1.9) \\
15(6.9)\end{array}$ & 0.001 \\
\hline $3-4$ & $\begin{array}{l}\text { BDHS, } 07 \\
\text { Tea workers' children }\end{array}$ & $\begin{array}{l}158(15.1) \\
60(32.1)\end{array}$ & $\begin{array}{l}25(2.4) \\
14(7.5)\end{array}$ & 0.001 \\
\hline $4-5$ & $\begin{array}{l}\text { BDHS, } 07 \\
\text { Tea workers' children }\end{array}$ & $\begin{array}{l}162(15.3) \\
60(34.7)\end{array}$ & $\begin{array}{l}15(1.4) \\
8(4.6)\end{array}$ & 0.001 \\
\hline
\end{tabular}

${ }^{*}$ Chi-square test; "Figure within parenthesis indicates the percentage

Table-VII

Distribution of nutrition status (stunting) of the children: Comparison between national data and result of the study

\begin{tabular}{|c|c|c|c|c|}
\hline \multirow{3}{*}{$\begin{array}{l}\text { Age } \\
\text { (year) }\end{array}$} & \multirow{3}{*}{ Study group } & \multicolumn{2}{|c|}{ Height for age (stunting) } & \multirow{3}{*}{ p value* } \\
\hline & & \multicolumn{2}{|c|}{ Z score } & \\
\hline & & Moderate (-2 to -3$)$ & Severe $(<-3)$ & \\
\hline \multirow[t]{2}{*}{$1-2$} & BDHS,07 & $437(40.5)^{\#}$ & $147(13.6)$ & 0.001 \\
\hline & Tea workers' children & $90(49.7)$ & $39(21.6)$ & \\
\hline \multirow[t]{2}{*}{$2-3$} & BDHS,07 & $576(53.2)$ & $231(21.3)$ & 0.011 \\
\hline & Tea workers' children & $131(59.8)$ & $53(24.2)$ & \\
\hline \multirow[t]{2}{*}{$3-4$} & BDHS,07 & $592(54.0)$ & $239(23.1)$ & 0.007 \\
\hline & Tea workers' children & $120(64.2)$ & $47(25.1)$ & \\
\hline \multirow[t]{2}{*}{$4-5$} & BDHS,07 & $482(45.6)$ & $186(15.9)$ & 0.003 \\
\hline & Tea workers' children & $99(57.2)$ & $33(19.1)$ & \\
\hline
\end{tabular}

${ }^{*}$ Chi-square test; ${ }^{~ F i g u r e ~ w i t h i n ~ p a r e n t h e s i s ~ i n d i c a t e s ~ t h e ~ p e r c e n t a g e ~}$

Table-VIII

Distribution of nutrition status (under weight) of the children: Comparison between national data and result of the study

\begin{tabular}{|c|c|c|c|c|}
\hline \multirow{3}{*}{$\begin{array}{l}\text { Age } \\
\text { (year) }\end{array}$} & \multirow{3}{*}{ Study group } & \multicolumn{2}{|c|}{ Weight for age (under weight) } & \multirow{3}{*}{ p value* } \\
\hline & & \multicolumn{2}{|c|}{ Z score } & \\
\hline & & Moderate(-2 to -3$)$ & Severe $(<-3)$ & \\
\hline \multirow[t]{2}{*}{$1-2$} & $\mathrm{BDHS}, 07$ & $422(39.1)^{\#}$ & $126(11.7)$ & \multirow[t]{2}{*}{0.001} \\
\hline & Tea workers' children & $108(59.7)$ & $28(15.5)$ & \\
\hline \multirow[t]{2}{*}{$2-3$} & $\mathrm{BDHS}, 07$ & $482(44.5)$ & $152(14.0)$ & \multirow[t]{2}{*}{0.011} \\
\hline & Tea workers' children & $115(52.5)$ & $37(16.9)$ & \\
\hline \multirow[t]{2}{*}{$3-4$} & $\mathrm{BDHS}, 07$ & $490(46.8)$ & $156(14.9)$ & \multirow[t]{2}{*}{0.007} \\
\hline & Tea workers' children & $109(58.3)$ & $28(15.0)$ & \\
\hline \multirow[t]{2}{*}{$4-5$} & BDHS,07 & 490 (46.3) & $115(10.9)$ & \multirow[t]{2}{*}{0.001} \\
\hline & Tea workers' children & $103(59.5)$ & $25(14.5)$ & \\
\hline
\end{tabular}

${ }^{*}$ Chi-square test; "Figure within parenthesis indicates the percentage 


\section{Discussion}

The study was conducted on the children of tea workers. The ethnic or racial factors as the cause of difference in growth is much less important factor in cases of prepubertal children than environmental factors $^{13}$. This study has enabled us to compare nutritional status of Bengali children with that of tea workers' children.

Analysis of data suggest that early marriage was common in the tea workers as because $64.76 \%$ of attending mothers were less than 18 years of age. This finding is consistent with national data. About 74\% girls aged below 18 years are married in Bangladesh ${ }^{14}$. Child marriage (marriage at $<18$ years) in South Asia is also high which increased from 45\% to $53 \%$ in between $1987-2006^{15}$.

If we consider the educational status of the mothers of tea gardens, it is far behind from national level. About $90 \%$ of them are illiterate and no body passed HSC, whereas $70.7 \%$ adult female (>15 years) were illiterate in the year of 1999 in Bangladesh ${ }^{16}$.

About $18.6 \%$ of attending mothers had history of abortion, stillbirth or infant death. This result suggests poor antenatal care and lack of safe delivery facility among them. Coverage of antenatal care is relatively low even in national level. Seventy percent of the tea workers' family earn only < 2000 taka per month. An adult tea worker can earn only 26.75 taka after plucking at least $23 \mathrm{~kg}$ of tea leaves in a category ' $A$ ' tea garden. The amount is only 25.45 taka in case of children ${ }^{17}$. This finding is consistent with low income people of Bangladesh. About $50 \%$ of our people earn less than 1.25 US dollar per day and remains below international poverty line ${ }^{18}$. A study by Hong $\mathrm{R}$ and Banta JE indicate that household wealth inequality is strongly associated with childhood adverse growth rate (stunting). Children in the poorest $20 \%$ of households are more than three times as likely to suffer from adverse growth rate stunting as children from the wealthiest $20 \%$ of households ${ }^{19}$. So reduction of poverty is essential for improvement of nutritional status of the tea workers' children.

Although breast feeding is almost universal in Bangladesh, proper breast feeding is on the decline due to several factors. Luckily tea workers have high rate of breast feeding, nearly $80 \%$ at least for first 6 months. It was much higher than Bengali population which was only about $42 \%$ according to Bangladesh Breast-Feeding Foundation. A study showed that exclusively breast fed children were nutritionally better than the children who are not breastfed ${ }^{20}$. Possibly poor maternal educational status and poverty helped the children of tea garden for exclusive breast feeding as because some educated mother does not continue breast feeding - here education acts as a proxy for socioeconomic status ${ }^{21}$.

Complementary foods given to infants in tea gardens are often nutritionally inadequate and leading to malnutrition. Only 22\% children aged 6-9 months are given foods from animal sources ${ }^{22}$. Situation is much more worse for children of tea workers. About $85 \%$ of them are offered with rice gruel and $10 \%$ started with khichuri.

Multiple Indicator Cluster Survey, Bangladesh 2006 shows that the proportion of 12-23 months old who are fully immunized is $81 \%$ and this study showed $95 \%$ of children in tea gardens are fully immunized as per EPI schedule. Diarrhoea and ARI were the two common diseases among these children. About 99\% of the workers drank tube well water but only $51 \%$ of them used sanitary latrine. These parameters are equivalent to national level. In 2003, 97\% of rural people had access to safe drinking water and $48.2 \%$ rural people used safe latrine ${ }^{23}$. Almost all tea workers live in kacha house. The condition is much more worse from that was found by Paul-Mazumder, 2001 in which $16.2 \%$ tea workers lived in brick-built tin shed house ${ }^{24}$.

Body mass index of the attending mothers also showed tea workers as a starving population. One third (34\%) of ever married Bangladeshi women have a low body mass index indicating chronic energy deficiency ${ }^{25}$. Forty percent of the tea worker mothers had BMI between 18.5-20 and 9.52\% had BMI <16. Individual with $\mathrm{BMI}<16$ are considered at "high risk of mortality from starvation"26.

Mid upper arm circumference of the studied children showed more than half of the children were malnourished which was further confirmed by Z scoring of weight for height (wasting), height for age (stunting) and weight for age (under weight). There was no marked difference among male and female child. But there was statistically significant difference among wasting, stunting and under weight in the children of tea workers from that obtained from recent national survey like Bangladesh Demographic and Health Survey ${ }^{27}$. All the parameter were higher in the children of tea workers rendering them one of the most vulnerable groups in our country. A study by Karim and Khan showed that $49 \%$ of children were under weight, $43 \%$ were stunted and $20 \%$ were wasted $^{28}$. Another study in 1995-96 
showed that $64.2 \%$ of all children were underweight whereas $60.4 \%$ and $17 \%$ were stunted and wasted respectively ${ }^{29}$. But this study unveils much higher level of malnutrition among the children of tea workers than that of national surveys. Prevalence of wasting is $42.3 \%$ whereas those of stunting and underweight are $80.2 \%$ and $73 \%$ respectively.

\section{Conclusion}

The study gives us the picture of the severity of malnutrition among the children of tea workers which has significantly higher value than that obtained from national surveys. This study also focuses on some other contributing factors which may adversely affect child nutrition like maternal education and health, early marriage, low income, housing, sanitation etc. Most of these parameters are deviant in this population. The high prevalence of malnutrition in the early years of life justifies the targeting the children of tea workers at an early age for effective improvement in their nutritional status including their socio-economic condition.

\section{References}

1. Heird CW. Food Insecurity, Hunger and Undernutrition. In: Behrman ER, Kliegman MR, Jensen $\mathrm{BH}$, Stanton FB, editors. Nelson Textbook of Pediatrics. $18^{\text {th }}$ ed. Philadelphia: WB Saunders Co; 2008: p 229.

2. Poverty Reduction Begins With Children. United Nations Children Fund; March 2000. p 72.

3. Poverty in Bangladesh Building on Progress. The World Bank, March 2003.

4. Report of Poverty Monitoring Survey 2004, Bangladesh Bureau of Statistics.

5. Demographics of Bangladesh [accessed on 1 May 2009]. Available from: "http://en.wikipedia. org/wiki/ Demographics of Bangladesh".

6. Israt RM, Khan HSM. Factors Causing Malnutrition Among Under Five Children In Bangladesh. Pak J Nutr 2006; 5: 558.

7. Bairagi R, Chowdhury MK. Socioeconomic and Anthropometric Status and Mortality of Young Children in Rural Bangladesh. Int J Epidemiol 1994; 23: 1179-84.

8. Islam MA, Rahman MM, Mahalanbish D. Maternal and Socioeconomic Factors and the Risk of Severe Malnutrition in a Child : A Case Control study. Eu J Nutr 1994; 48: 416-24.

9. Achariya J. Aadibashi Jonopoder Pothey Prantore. $1^{\text {st }}$ ed. Dhaka: Shrabon Prokashoney; 2005.
10. Tea Industry [accessed on 1 January 2009] available from Banglapedia. SBD T_0100.htm.

11. Kajol I. Surma Upottokar Cha Sramik Andolon: Oteet O Bortoman. $1^{\text {st }}$ ed. Dhaka: Probash Prokashoney; 2006.

12. Bishwas R. Uttorbanger Jati O Upojati. $1^{\text {st }} \mathrm{ed}$. Dhaka: Punoscho Prokashoney; 1998.

13. Martorell J, Melina C, Klein R. Height and Weight Standards for Preschool Children: How Relevant are Ethnic Differences in Growth Potential. Lancet 1974; 611-15.

14. Multiple Indicators Cluster Survey 2006. BBSUNICEF, Dhaka.

15. The State of World's Children 2007.

16. Bangladesh Data Profile, Sustainable Development Networking Project Bangladesh.

17. Bangladeshiyo Cha Sangshad. Annual Report, 19997-98.

18. The state of World's Children 2009.

19. Hong R, Banta JE, Betancourt JA. Int J Equity Health 2006; 5: 15.

20. Giashuddin MS, Kabir M, Rahman A, Hannan MA. Indian J Pediatr 2003; 70: 471-75.

21. Islam MS, Becker S. Interrelationships Among Certain Socio-economic Variables in A Rural Population of Bangladesh. Rural Demography 1979; 6: 51-65.

22. Surveillance Study on Breast Feeding and Complementary Feeding Situation and Nutrition Status of Mothers and Children in Bangladesh. Breast Feeding Foundation; 2005.

23. Statistics for Monitoring Attainment of MDGs in Bangladesh. Bangladesh Bureau Statistics 2006.

24. Mazumder PP, Sarker RMM. The Bangladesh Development Studies 2003; 20: 65-93.

25. National Strategy for Infant and Young Child Feeding in Bangladesh, April 2007.

26. Criteria from WHO Expert Committee Report on Anthropometry, WHO TRS 854, 1995.

27. Bangladesh Demographic and Health Survey 2007.

28. Karim R, Khan INM, Akhtaruzzaman M. The Bangladesh Development Studies 2004; 30: 12935.

29. Ahmed SS, Jahan K, Arefin S. Nutritional Status of Under Six Children in Bangladesh: Evidence Based From Nutrition Survey of Bangladesh, 199596. Jalalabad Medical Journal 2005; 2 : 17-19. 